\title{
Nonapeptides and the evolution of social group sizes in birds
}

\author{
James L. Goodson* and Marcy A. Kingsbury
}

Department of Biology, Indiana University, Bloomington, IN, USA

Edited by:

Fernando Martinez-Garcia, Universidad de Valencia, Spain

\section{Reviewed by:}

Enrique Lanuza, Universidad de Valencia, Spain

Jacques Balthazart, University of Liege, Belgium

\section{${ }^{*}$ Correspondence:}

James L. Goodson, Department of

Biology, Indiana University, 1001 East

3rd Street, Bloomington, IN 47405,

USA.

e-mail: jlgoodso@indiana.edu
Species-typical patterns of grouping have profound impacts on many aspects of physiology and behavior. However, prior to our recent studies in estrildid finches, neural mechanisms that titrate species-typical group-size preferences, independent of other aspects of social organization (e.g., mating system and parental care), have been wholly unexplored, likely because species-typical group size is typically confounded with other aspects of behavior and biology. An additional complication is that components of social organization are evolutionarily labile and prone to repeated divergence and convergence. Hence, we cannot assume that convergence in social structure has been produced by convergent modifications to the same neural characters, and thus any comparative approach to grouping must include not only species that differ in their species-typical group sizes, but also species that exhibit convergent evolution in this aspect of social organization. Using five estrildid finch species that differ selectively in grouping (all biparental and monogamous) we have demonstrated that neural motivational systems evolve in predictable ways in relation to species-typical group sizes, including convergence in two highly gregarious species and convergence in two relatively asocial, territorial species. These systems include nonapeptide (vasotocin and mesotocin) circuits that encode the valence of social stimuli (positive-negative), titrate group-size preferences, and modulate anxiety-like behaviors. Nonapeptide systems exhibit functional and anatomical properties that are biased toward gregarious species, and experimental reductions of nonapeptide signaling by receptor antagonism and antisense oligonucleotides significantly decrease preferred group sizes in the gregarious zebra finch. Combined, these findings suggest that selection on species-typical group size may reliably target the same neural motivation systems when a given social structure evolves independently.

Keywords: aggression, bird, evolution, mesotocin, oxytocin, sociality, vasopressin, vasotocin

\section{INTRODUCTION: EVOLUTION AND DIVERSITY IN SOCIAL PHENOTYPES}

Vertebrate animals affiliate in multiple contexts, but sexual behavior is likely the only context of affiliation that is nearly ubiquitous across vertebrate species. Thus, the various forms of social contact that we observe across species are subject to independent evolution in different taxa, although some forms are conserved across very large clades. The provision of maternal care to offspring post-hatching or post-parturition is a good example. This kind of behavior typifies most mammals and most birds, but mammals and birds have evolved extended maternal care independently (Alcock, 2009; Goodenough et al., 2010). Studies of many vertebrate taxa demonstrate that the neural mechanisms of sexual behavior are strongly conserved (Goodson, 2005; Martinez-Garcia et al., 2008), and limited evidence suggests that mechanisms of parental care are at least grossly similar in mammals and birds, as well (Buntin et al., 2006). However, almost no generalizations can be made regarding the mechanisms of evolutionarily labile aspects of social behavior, such as cooperative breeding, mating systems, and grouping. These variables represent major defining features of species-specific social structures and have therefore garnered an extraordinary amount of attention from evolutionary biologists and behavioral ecologists. However, evolutionarily labile behaviors pose fairly extreme challenges for comparative neurobiology, largely for reasons of feasibility. For instance, after two decades of intensive research, the neural mechanisms of selective partner preference (a hallmark of monogamy), paternal care, and alloparental care are reasonably well understood for only a single species, the monogamous prairie vole (Microtus ochrogaster), and we know a limited amount about the critical variables that differentiate prairie voles from other non-monogamous vole species (Carter et al., 2008; Donaldson and Young, 2008; Aragona and Wang, 2009; Ross and Young, 2009; McGraw and Young, 2010). What we do not yet know is whether neural mechanisms have evolved convergently in other monogamous or alloparental species, although this is a matter of substantial current interest (Fink et al., 2006; Goodson and Thompson, 2010; Turner et al., 2010).

This example points out a fundamental difference in the approaches to social organization that are employed by evolutionary biologists and neuroethologists. Evolutionary biologists can often bring extensive information to bear on a given question, perhaps using data from dozens or hundreds of species, and analyze it in a phylogenetically corrected way that allows the extrapolation of general patterns. To some extent, neurobiologists can employ similar techniques if they are based on anatomical characteristics or genes (Northcutt, 2008; Pollen and Hofmann, 2008). Nonetheless, we cannot make any strong claims about evolutionary patterns of regulation if the experimental approaches 
of behavioral neuroscience are not employed, and it simply not feasible to replicate experiments in dozens or hundreds of species. For this reason, neuroethological approaches to questions about evolutionarily labile behaviors will likely continue to be somewhat different from evolutionary biological approaches, even when both are employed by the same investigators. However, if neuroethologists want to establish predictive validity for other species, comparative experimentation focused on divergent and convergent evolution is essential. In the sections that follow, we describe a quasi-experimental approach that we have taken to study convergent and divergent evolution in grouping behavior within the estrildid finch family. Although only five species have been used (Table 1), they have been carefully selected and our findings should therefore have good predictive validity for other estrildid finches. Whether our findings can be extrapolated to other vertebrate taxa is a matter of greater speculation, and a topic that we will return to in the Section "Conclusion."

\section{A COMPARATIVE APPROACH TO GROUPING}

Sociality sensu stricto, as defined by grouping behavior (Alexander, 1974), has broad influences on other important variables such as reproductive behavior, disease transmission, resource exploitation, and defense (Moller and Birkhead, 1993; Krause and Ruxton, 2002; Silk, 2007), but has not previously been examined in neurobiological studies, likely because grouping is difficult to isolate from other aspects of ecology and behavior, such as mating system and patterns of parental care. For instance, rodent species that differ in their grouping behavior also differ in whether they are monogamous or polygamous, and whether the father contributes to parental care (King, 1968; Tamarin, 1985). However, if we want to examine the neural mechanisms that titrate species-typical group-size preferences, control for such variables is very important, given that shared mechanisms (particularly neuroendocrine mechanisms) often regulate numerous aspects of social behavior (e.g., pair bonding, parental care, and affiliation) and related aspects of physiology (e.g., hormone levels and stress physiology; Carter et al., 2008; Neumann, 2009; Goodson and Thompson, 2010).

Birds offer excellent opportunities to study grouping, since we can identify closely related species that are virtually identical in most aspects of behavior and ecology, but that nonetheless exhibit extreme variation in sociality, ranging from territorial pairs to massive flocks. The finch family Estrildidae is a standout in this regard. The majority of estrildid species (approximately 141 total; Clements, 2007) form small groups of about 6-12 birds when they are not breeding, and then loosely distribute themselves for nesting without strong territoriality. Defense of a breeding territory has evolved in five to six species across three genera. Colonial breeding has also evolved in several genera, although most colonies are small (perhaps 5-10 breeding pairs). Available evidence suggests that all estrildids exhibit biparental care and long-term (typically life-long), socially monogamous pair bonds (Immelmann, 1965; Goodwin, 1982).

Table 1 | Behavioral and ecological characteristics of estrildid finch species that have been used for studies of grouping behavior. For relevant references, see footnote 1.

\begin{tabular}{|c|c|c|c|c|c|}
\hline Species & Grouping behavior & Mating system & Parental care & Distribution & Breeding cycle \\
\hline $\begin{array}{l}\text { Melba finch (Pytilia } \\
\text { melba) }\end{array}$ & Territorial pairs & $\begin{array}{l}\text { Long-term socially } \\
\text { monogamous }\end{array}$ & Biparental & $\begin{array}{l}\text { Wide distribution in } \\
\text { sub-Saharan Africa; } \\
\text { desert and dry } \\
\text { savannah }\end{array}$ & $\begin{array}{l}\text { Opportunistic; in years with late } \\
\text { rains, may delay breeding by } \\
\text { several months relative to modal } \\
\text { timing, which coincides with peaks } \\
\text { in seeding grasses and insect } \\
\text { abundance }\end{array}$ \\
\hline $\begin{array}{l}\text { Violet-eared waxbill } \\
\text { (Uraeginthus granatina) }\end{array}$ & Territorial pairs & $\begin{array}{l}\text { Long-term socially } \\
\text { monogamous }\end{array}$ & Biparental & $\begin{array}{l}\text { Southern Africa; desert } \\
\text { and dry savannah }\end{array}$ & Comparable to Melba finch (above) \\
\hline $\begin{array}{l}\text { "Angolan" blue waxbill1 } \\
\text { (Uraeginthus }\end{array}$ & $\begin{array}{l}\text { Modestly gregarious (groups } \\
\text { of 8-40); loosely distribute for }\end{array}$ & $\begin{array}{l}\text { Long-term socially } \\
\text { monogamous }\end{array}$ & Biparental & $\begin{array}{l}\text { Southern Africa; desert } \\
\text { and dry savannah }\end{array}$ & Comparable to Melba finch (above) \\
\hline
\end{tabular}

angolensis) breeding, but small foraging parties are still observed

\section{Spice finch² (Lonchura Highly gregarious and} punctulata) colonial; flocks may contain $>1000$ birds, but typically fewer

Zebra finch

(Taeniopygia guttata)

Long-term socially Biparental
monogamous
Long-term socially Biparental
monogamous; low
promiscuity

\begin{abstract}
Wide distribution in Indo-Asia; both arid and mesic grasslands, rice paddies
\end{abstract}

Wide distribution in arid regions of Australia, including central Outback
Opportunistic; may breed during any month dependent upon rainfall and seeding grasses, but with strong post-monsoonal peaks that are fairly seasonal

Highly opportunistic; may breed during any month dependent upon rainfall and seeding grasses

groups up to 300

'The genus Uraeginthus contains three species of blue waxbill that are each known by multiple common names. Thus, although U. angolensis is most typically referred to as simply "blue waxbill," we have referred to this species as "Angolan blue waxbill" in our publications in order to clearly differentiate them from other species.

${ }^{2}$ This species is commonly encountered in the scientific literature, but under a variety of common names, including spotted munia, nutmeg mannikin, and spice finch. 
We have collected five estrildid finch species that exhibit large and seasonally stable differences in grouping, but are otherwise closely matched in behavior and ecology (Table 1). In addition to being socially monogamous and biparental, as already noted, all of these species live in arid or semi-arid grassland scrub and breed opportunistically or semi-opportunistically in relation to rainfall (Skead, 1975; Goodwin, 1982; Zann, 1996; Goodson et al., 2006). These include two territorial African species that live as male-female pairs year-round (violet-eared waxbill, Uraeginthus granatina, and melba finch, Pytilia melba); two highly gregarious, colonially breeding species that exhibit modal group sizes of approximately 100 (zebra finch, Taeniopygia guttata, and spice finch, Lonchura punctulata); and a moderately gregarious species, the Angolan blue waxbill (Uraeginthus angolensis), which exhibits a modal group size of approximately 20 . The two territorial species have evolved their territorial behavior independently and the two colonial species have also evolved their extreme sociality independently ${ }^{1}$ (Goodson et al., 2006). The gregarious Angolan blue waxbill is sympatric with both the Melba finch and violet-eared waxbill, and our laboratory population of these three species has been established through the breeding of birds that were caught from a single location in the Kalahari thornscrub of South Africa in 2001. We have obtained zebra finches and wild-caught spice finches (likely of an Indian subspecies) from commercial suppliers.

The inclusion of the zebra finch is an important asset to our research program because domestic zebra finches are both behaviorally robust and readily available, which makes them an ideal species for extensive laboratory studies. Domestic zebra finches are behaviorally indistinguishable from wild-caught zebra finches

${ }^{1}$ We have compiled information on estrildid sociality from available sources, but most particularly Goodwin (1982), who provides an extensive review of estrildid biology and good summaries of much non-English literature (including a number of relevant works in German by K. Immelmann, G. Immelmann, P. Kunkel and J. Nicolai). We additionally consulted English-language publications by Immelmann (1965), Payne (1998), Skead (1975), Harrison (1962), Zann (1996), and Ziegler (1971). Estrildid systematics: Estrildid systematics have been argued for many decades (Delacour, 1943; Mayr, 1968; Christidis, 1987a,b), but fortunately, the various arrangements are largely irrelevant to our conclusions regarding convergent evolution in territoriality and extreme coloniality. A species-level molecular phylogeny is not yet available for the Estrildidae, but a genus-level molecular phylogeny has been published by Sorenson et al. (2004). Note that Sorenson has place the violeteared waxbills into a new genus Granatina (two species), a closely related sister genus of Uraeginthus. However, pending a species-level phylogeny, we still assign the violet-eared waxbill to Uraeginthus, largely for purposes of consistency with our previous publications and the synthetic work of Goodwin (1982). Independent evolution of territoriality: The majority of estrildid species form small parties outside of the breeding season and loosely distribute for breeding, without aggressive defense of a territory. Territoriality is exhibited in three genera (Euschistospiza, Pytilia, and Uraeginthus), and the closest outgroups for each of these three genera are typical, non-territorial estrildids. Of the five species in the Uraeginthus genus, only the violet-eared waxbill (U. granatina) and the closely related purple grenadier (U. ianthinogaster) aggressively maintain exclusive breeding territories (these species are assigned to Granatina by Sorenson et al., 2004). Immelmann (cited in Goodwin, 1982) reports that the territories of U. granatina are several hundred meters square and that intruders are promptly driven out. Although U. ianthinogaster appears to be much the same, this species is occasionally encountered in small parties during the non-breeding season (Goodwin, 1982), whereas adult pairs of U. granatina do not associate with other pairs (B. M. Mines and J. L. Goodson, unpublished observations; includes 3 years of field observations by B. M. Mines). Other Uraeginthus species are much more social; e.g., the Angolan blue waxbill (or blue-breasted cordon bleu, $U$. angolensis) tends to breed in a semi-colonial manner, with each pair occupying a clump of bushes (Skead, 1975; Goodwin, 1982). The closest outgroups to Uraeginthus, the bluebills (Spermophaga; three species) and
(Morris, 1958) and virtually their full range of social behavior can be observed in the lab. For instance, we are able to quantify over 20 behaviors while zebra finches are interacting in a colony environment, and can readily track the natural formation of monogamous pair bonds (Goodson et al., 1999; Kabelik et al., 2009).

\section{NEURAL CIRCUITS OF TERRITORIAL AGGRESSION, AVERSION, AND SOCIALITY IN SONGBIRDS}

Vertebrates possess a core social behavior network within the basal ("limbic") forebrain and midbrain (Figure 1) that is evolutionarily conserved across all taxa, but is particularly stable across the amniote clades giving rise to birds and mammals, as demonstrated by a wide range of functional and anatomical studies. This network includes the medial extended amygdala (including the medial bed nucleus of the stria terminalis, BSTm), lateral septum (LS), anterior hypothalamus $(\mathrm{AH})$, ventromedial hypothalamus (VMH), midbrain central gray (CG; or periaqueductal gray), and the ventral tegmental area, although these structures are not strictly social in function and contribute to other core networks for the regulation of behavior and physiology. All of these areas express high densities of sex steroid receptors, and in contrast to most other areas of the brain that influence social behavior, they are absolutely essential for basic functions such as the expression of sexual, aggressive, and parental behaviors, and also for the regulation of anxiety, social recognition, and approach-avoidance processes (Newman, 1999; Goodson, 2005).

Birds exhibit mammal-like patterns of immediate early gene (IEG) induction in this network across a variety of social contexts, including territorial aggression, a context that is strongly relevant to

seedcrackers (Pyrenestes; three species) are also typical of the estrildids, in that they may be encountered in small parties when not breeding, and loosely distribute for breeding without defending territories. Hence, the evolution of territoriality in the violet-eared waxbill and closely related purple grenadier appears to be a shared derived character of these two species alone. Similarly, the Melba finch is the only territorial species within Pytilia (five species), and the closest outgroup to the Pytilia genus, Lagonosticta, is comprised of 10 firefinch species that are all typical, social estrildids. Independent evolution of extreme coloniality: Zebra finches and spice finches belong to a large group of predominantly Australasian finches, although this group is largely divisible into two distinct clades, one containing the zebra finch (approximately 11 species) and the other containing the spice finch (approximately 30 species). Most species in the zebra finch clade are modestly gregarious, at least during the non-breeding season, and many form small, loose colonies. However, there are also a few species that are markedly less social, particularly the Stagonopleura (firetail) and Oreostruthus (mountain firetail) species, and despite the fact that numerous species in the zebra finch clade are social during breeding, a high level of coloniality has evolved only in the zebra finch and chestnut-eared finch ( $T$. castanotis; historically considered a subspecies of the zebra finch; Goodwin, 1982; Zann, 1996). Based on a large number of counts by Zann and colleagues (reviewed in Zann, 1996), the average zebra finch breeding colony includes 66 adults (an unknown number of dependent young would also be present), and the average nonbreeding flock contains 107 birds. The owl finch (T. bichenovii), which is arguably the next most social species in the zebra finch clade, displays a level of sociality well below that of the zebra finch, with typical flocks numbering only 4-20 individuals (Immelmann, 1965). Thus, parsimony strongly suggests that the zebra finch's uniquely high level of colonial behavior is not ancestral for its clade. Similarly, only three of the species in the other Australasian clade exhibit a level of coloniality that is comparable to the zebra finch, including the spice finch (see Immelmann, 1965). Several species form only small non-breeding parties and distribute for breeding, while the majority of species form non-breeding flocks and breed with a few pairs close together. These observations, combined with the considerations of the zebra finch clade, firmly support the view that extremely gregarious behavior, characterized by large colonies and non-breeding flocks of hundreds to thousands of individuals, has evolved independently in the spice finch and zebra finch. 

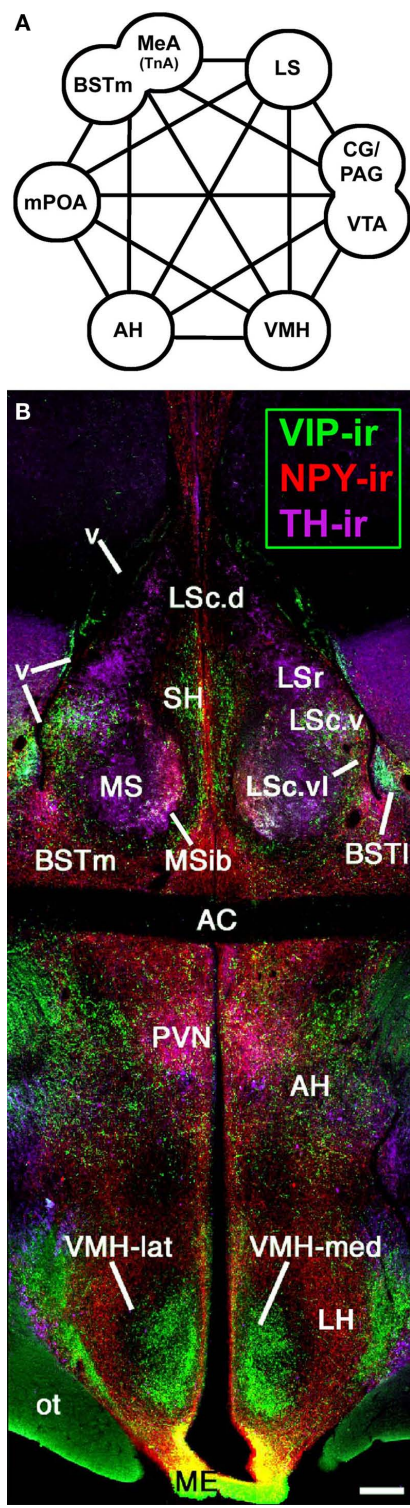

FIGURE 1 |An evolutionarily conserved suite of brain regions that regulate vertebrate social behavior. (A) The core components of the social behavior network include numerous areas of the basal forebrain - the medial extended amygdala (medial amygdala, MeA, or taenial amygdala, TnA, plus the medial bed nucleus of the stria terminalis, BSTm), medial preoptic area (mPOA), anterior hypothalamus $(\mathrm{AH})$, ventromedial hypothalamus $(\mathrm{VMH})$, and lateral septum (LS), as well as areas of the midbrain, most notably the central gray (CG; or periaqueductal gray, PAG) and the ventral tegmental area (VTA). Modified from Newman (1999) and Maney et al. (2008). (B) A photomontage of a female zebra finch brain at the level of the anterior commissure (AC). Immunocytochemical triple-labeling for vasoactive intestinal polypeptide (VIP), neuropeptide Y (NPY), and tyrosine hydroxylase (TH) shows the location of the $\mathrm{AH}$ and multiple zones of the LS, BST, and VMH. The topography shown here is very similar across vertebrate groups, particularly among amniotes. Scale bar $=200 \mu \mathrm{m}$. Modified from Goodson, 2005. Other abbreviations: BSTI, lateral bed nucleus of the stria terminalis; Hp, hippocampus; LH, lateral hypothalamus; LSc, caudal division of the lateral septum (dorsal, ventrolateral, and ventral zones denoted as LSc.d, LSc. $\mathrm{Vl}$, and LSc.v, respectively); LSr, rostral division of the lateral septum; ME, median eminence; MS, medial septum; MSib, internal band of the medial septum; ot, optic tract; OM, occipitomesencephalic tract; PVN, paraventricular nucleus of the hypothalamus; $\mathrm{SH}$, septohippocampal septum; v, lateral ventricle. species differences in sociality. IEG proteins such as Fos and egr-1 are rapidly inducible transcription factors that are proxy markers of neuronal activity. Following resident-intruder encounters in territorial rodents (Kollack-Walker et al., 1997; Motta et al., 2009) and simulated territorial intrusion (STI; playback of song and presentation of a caged decoy male) in male song sparrows, significant activation is observed in forebrain areas such as the BSTm, LS, paraventricular nucleus of the hypothalamus (PVN), AH, and the lateral portion of the VMH (Goodson and Evans, 2004; Goodson et al., 2005b), as well as midbrain areas such as the CG (Maney and Ball, 2003). IEG results are extensively comparable in winter and summer sparrows (Goodson and Evans, 2004; Goodson et al., 2005b). Notably, IEG responses of the AH, PVN, and multiple zones of the LS correlate negatively with aggression (Goodson et al., 2005b), and the case is much the same in hamsters and mice, such that fighting-induced Fos expression is higher in subordinate versus dominant animals (Kollack-Walker et al., 1997; Motta et al., 2009). This applies to most aggression-related areas in the brain, and we have obtained very similar results in the territorial violeteared waxbill (J. L. Goodson, S. E. Schrock, and M. A. Kingsbury, unpublished observations).

Neural circuitry that regulates grouping is substantially less well known. As an initial approach to this issue, we examined the neural responses of territorial and gregarious estrildids to samesex conspecifics (Goodson et al., 2005a). Subjects were isolated in a quiet room and then exposed to a same-sex conspecific through a wire barrier. Importantly, this manipulation elicits very little overt behavior and thus species differences in neural response should primarily reflect species differences in perceptual or motivational processes. Despite the simplicity of this paradigm, Fos and egr-1 responses clearly distinguish the territorial from gregarious (flocking) species, including differences between the two sympatric Uraeginthus species described in the previous section. Overall, territorial birds exhibit significantly greater IEG responses in the medial extended amygdala (especially the BSTm), ventrolateral LS, $\mathrm{AH}$, lateral VMH, and CG (and adjacent "intercollicular" territory that is now known to be homologous to the dorsal and dorsolateral CG of mammals; Goodson et al., 2005a; Kingsbury et al., 2011). This pattern is virtually identical to a pattern associated with aversive social stimulation in rodents (Sheehan et al., 2001; providing a good example of deep functional conservation in the social behavior circuits of vertebrate brains), but possible mechanisms of gregariousness were not evident at this level of analysis. This may partially reflect the fact that functionally distinct neurons are intercalated with one another in the various brain areas that influence social behavior (e.g., Choi et al., 2005). For instance, as described in the next section, Fos induction within arginine vasotocin (VT) neurons of the BSTm is strictly associated with affiliation-related stimuli, and following same-sex exposure, the gregarious species show greater Fos induction in the VT neurons than do territorial species (Goodson and Wang, 2006). However, as just noted, the overall Fos response of the BSTm is greater in the territorial birds (Goodson et al., 2005a), suggesting that the VT neurons are intermingled with other neurons that exhibit opposing profiles of response. These hypothetical "aversion" neurons have not yet been identified, although aromatase-expressing neurons, which are numerous in the BSTm and mostly negative for VT (Kabelik 
et al., 2010), are possible candidates. Consistent with this idea, recent findings in mice suggest that estrogen signaling within the BSTm is important for the regulation of resident-intruder aggression (Trainor et al., 2006, 2007) and inhibits affiliative behavior in male prairie voles (Lei et al., 2010).

\section{NONAPEPTIDE SYSTEMS: PHENOTYPIC DIVERSITY AND THE SPECIES-SPECIFIC ASSIGNMENT OF SOCIAL VALENCE}

The nine amino acid neuropeptides, or "nonapeptides," are among the most interesting modulators of social behavior identified to date. Although many anatomical and functional properties of nonapeptide systems are strongly conserved across all vertebrate taxa (and in the case of neurosecretory magnocellular neurons, perhaps across all bilaterians; Tessmar-Raible et al., 2007), there is substantial diversity in receptor distributions and nonapeptides have been extensively linked to behavioral variation across individuals, sexes, and species (Goodson and Bass, 2001; De Vries and Panzica, 2006; Donaldson and Young, 2008; Goodson, 2008).

Duplication of the VT gene in early jawed vertebrates gave rise to two nonapeptide lineages, which include the mammalian peptides arginine vasopressin (VP; homolog of VT) and oxytocin (OT). Most non-mammalian vertebrates express VT and an OT-like peptide, such as isotocin, found in ray-finned fishes, or mesotocin (MT), which is ubiquitously expressed in non-mammalian tetrapods (Acher, 1972; Hoyle, 1999). All jawed vertebrates express their two nonapeptide forms in both magnocellular and parvocellular neurons of the preoptic area and hypothalamus, which in amniotes are located primarily within the supraoptic nucleus of the hypothalamus and the PVN (Moore and Lowry, 1998; Goodson, 2008). In rats, the parvocellular neurons of the PVN give rise to widespread projections in the brain (De Vries and Buijs, 1983), and this is almost certainly the same in other vertebrates. Lesions of the PVN in rats virtually eliminate VP projections to the caudal brainstem, but not other areas, and eliminate OT projections throughout the brain (De Vries and Buijs, 1983). Thus, given the strong similarities of MT and OT systems, it is likely the case that extrahypothalamic MT projections in birds are exclusively or almost exclusively derived from the PVN.

In addition to these hypothalamic cell groups, most tetrapods exhibit a very unique VT/VP cell group of the BSTm, which in some mammals extends into medial amygdala proper. With only a few exceptions, these neurons and their projections to the LS and other basal forebrain areas have been found to be seasonally variable, exquisitely dependent on sex steroids, and sexually dimorphic (males $>$ females). In each of these respects, the extrahypothalamic VT/VP circuitry arising in the BSTm is among the most extremely plastic systems in the brain. Indeed, as demonstrated for many species of mammals, amphibians, birds, and reptiles, this circuitry typically disappears in animals that are in non-reproductive condition or otherwise deprived of sex steroids (Goodson and Bass, 2001; De Vries and Panzica, 2006). However, in estrildids that exhibit opportunistic breeding and have no apparent endogenous reproductive cycles, no such collapse is observed, although basal transcriptional activity [as measured by constitutive expression of Fos protein in VT-immunoreactive (-ir) neurons] is nonetheless regulated by androgens (Kabelik et al., 2010). Thus, of the finches that we have examined, large seasonal fluctuations in VT immunoreactivity are found only for the spice finch, a species that exhibits photorefractoriness and endogenous rhythms of reproductive physiology that correlate with monsoon cyclicity (Goodwin, 1982; Chaturvedi and Prasad, 1991; Sikdar et al., 1992; Hahn and MacDougall-Shackleton, 2008).

The VT/VP neurons of the BSTm project to numerous other areas of the basal forebrain where VT/VP modulates aggression, parental behavior, social recognition, and various affiliative and anxiety-like behaviors; and at least in male prairie voles, VP release in the ventral pallidum promotes partner preference (Donaldson and Young, 2008; Veenema and Neumann, 2008; Goodson and Thompson, 2010; Insel, 2010). Although these basal forebrain sites likely receive VT/VP from multiple hypothalamic cell groups in addition to the BSTm population, the relative contributions of the different cell groups are difficult to ascertain, given the extensive evidence for paracrine signaling and volumetric release from dendrites and soma (Ludwig and Leng, 2006; Goodson and Kabelik, 2009).

In order to determine the kinds of stimuli that different VT/ VP cell groups respond to (particularly those of the BSTm), we have conducted several experiments in which we have exposed animals to social stimuli or control conditions, and then sacrificed the animals $90 \mathrm{~min}$ later for immunohistochemical colocalization of VT and Fos (see Table 2 for a summary of studies). Experimental induction of Fos is still robust at $90 \mathrm{~min}$, but the half-life of Fos protein is only $45 \mathrm{~min}$ (Herdegen and Leah, 1998), and thus if cellular activity is depressed by our social manipulations, we can detect this as a reduction in Fos expression. These experiments did not include analyses of MT-Fos colocalization, since MT behavioral functions were unknown at the time, but we are now conducting these analyses with alternate tissue series from the same animals.

Using this approach, our experiments have demonstrated a remarkable sensitivity of the BSTm VT/VP cells to social valence (Figure 2). Relative to handled controls, VT-ir neurons in the territorial estrildid species decrease their Fos expression in response to same-sex stimuli (exposed through a wire barrier as described above), but increase Fos expression in response to their pairbond partner. In contrast, in colonial birds that form mixed-sex flocks, VT-ir cells in the BSTm increase their activity in response to both same-sex stimuli and competitive courtship interactions, but not following intense subjugation (Goodson and Wang, 2006). No sex differences were observed in any of these results and similar effects were not observed for VT-Fos colocalization in the PVN (J. L. Goodson and Y. Wang, unpublished observations). Notably, although the modestly gregarious Angolan blue waxbill shows only a small (and not significant) increase in VT-Fos colocalization following exposure to a same-sex conspecific, the response profile of this species is still significantly different from its territorial congener, the violet-eared waxbill. Species differences in VT signaling may be further magnified based on VT-ir cell numbers, which are approximately 10 times more abundant in the colonial species relative to other species (Goodson and Wang, 2006). Finally, adding onto the remarkable response profile of this cell group, recent experiments in male zebra finches demonstrate that the BSTm VT 
Table 2 |A summary of main findings from studies of nonapeptide systems in territorial (T), moderately gregarious (MG), and highly gregarious (HG) species of estrildid finches.

\section{Variable or manipulation}

Fos response of VT-ir neurons in the BSTm ${ }^{1}$

Constitutive VT-Fos colocalization in the BSTm (early AM baseline) ${ }^{1}$

VT-ir cell number in the BSTm

Fos response of VT-ir neurons in the PVN to same-sex conspecific stimuli2

${ }^{125} \mid-V_{1}$ antagonist binding in the $L^{3}$

$\mathrm{VT}$ infusions into the LS for tests of aggression ${ }^{4}$

$V_{1 \mathrm{a}}$ antagonist infusions into the LS (male zebra finches) ${ }^{5}$

Knockdown of VT production in the BSTm by antisense oligonucleotides (male zebra finches) ${ }^{6}$

${ }^{125}$-OT antagonist binding in the $\mathrm{LS}^{7}$

OT antagonist administrations (peripheral, intraventricular, and intraseptal; zebra finches) ${ }^{7}$
Result

To same-sex conspecifics: $T<M G<H G$

Socially negative stimuli decrease VT-Fos colocalization or have no effect

Socially positive stimuli increase VT-Fos colocalization

$\mathrm{T}<\mathrm{MG}=\mathrm{HG}$

$\mathrm{T}=\mathrm{MG}<\mathrm{HG}$

$\mathrm{T}=\mathrm{MG}=\mathrm{HG}$

$\mathrm{T}<\mathrm{MG}=\mathrm{HG}$

Inhibit territorial (resident-intruder) aggression in male violet-eared waxbills

Facilitate aggression in the context of mate competition in male zebra finches Potently decrease gregariousness (\% of total contact time spent with the larger of two groups) with no effects on total contact time

Potently increase anxiety-like behavior

Reduce mate competition aggression

Potently decreases gregariousness

Increases anxiety-like behavior

Modestly increases social contact time

Dorsal (pallial): $\mathrm{T}<\mathrm{MG}=\mathrm{HG}$

Ventral (subpallial): $\mathrm{T}=\mathrm{MG}<\mathrm{HG}(P=0.06)$

Dorsal-ventral ratio: $T<M G=H G$

Decrease preferences for the larger of two groups with no effect on total contact time

Decrease preferences for familiar versus novel groups

Some effects are female-specific

'Goodson and Wang (2006), also see Goodson et al. (2009b).

${ }^{2}$ J. L. Goodson and Y. Wang (unpublished observation).

${ }^{3}$ Goodson et al. (2006).

${ }^{4}$ Goodson (1998), Goodson and Adkins-Regan (1999), Goodson et al. (2004).

${ }^{5}$ Goodson et al. (2004), Kelly et al. (2011).

${ }^{6}$ Kelly et al. (2011).

${ }^{7}$ Goodson et al. (2009c).

neurons increase their Fos expression selectively in response to a positive social stimulus, but show no response to a positive nonsocial stimulus (Goodson et al., 2009b).

Our results in birds are consistent with other recent findings in mice, and may therefore represent a common feature of BSTm VT/ VP neurons across all tetrapods. In male C57BL/6J mice, BSTm VP neurons exhibit robust Fos responses to copulation (which is clearly a positive, affiliation-related stimulus) and very modest responses to non-aggressive same-sex chemoinvestigation, but show no greater Fos response to aggressive interactions than simple chemoinvestigation (Ho et al., 2010). Notably, the sensitivity of amygdala neurons to valence has been extensively characterized through neurophysiological and neuroimaging studies in mammals (Nishijo et al., 1988; Paton et al., 2006; also see Goodson and Thompson, 2010), but specific cell types that process valence have not previously been identified. Neurophysiological studies in monkeys demonstrate that neurons which exhibit stable preferences for positive or negative stimuli are intercalated (Paton et al., 2006), and thus the neurochemical identification of valence- sensitive populations represents an important step toward understanding how social value is encoded and used by the brain to regulate behavior.

\section{EVOLUTIONARY CONVERGENCE AND DIVERGENCE IN NEUROPEPTIDE RECEPTOR DISTRIBUTIONS: A SPECIAL STATUS FOR THE LATERAL SEPTUM?}

Species differences in the response profiles of various brain areas and specific cell group are likely coordinated, at least to an extent, by the differential expression of receptors for neuromodulators. In fact, using the five finch species already introduced, we have obtained good evidence that the distributions of binding sites for vasoactive intestinal polypeptide (VIP), VT, and MT all exhibit convergent and divergent evolution in relation to sociality (based on quantitative autoradiography using ${ }^{125} \mathrm{I}-\mathrm{VIP}$ and iodinated antagonists of OT and $\mathrm{V}_{\text {1a }}$ receptors; Goodson et al., 2006, 2009c). Remarkably, binding sites for all three peptides exhibit sociality-related evolution within the LS, indicating that the LS plays a special role in grouping. In order 

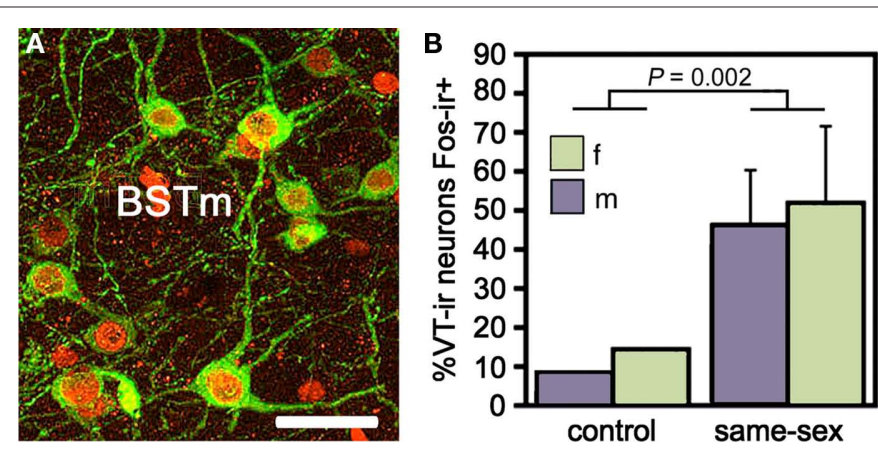

FIGURE 2 |Valence sensitivity of vasotocin (VT) neurons in the medial bed nucleus of the stria terminalis (BSTm), as demonstrated by socially induced changes in the immunocytochemical colocalization of VT and the proxy activity marker Fos. (A) Representative colocalization of VT (green) and Fos (red) in the BSTm of a male zebra finch following a courtship interaction. Note that most VT neurons express Fos. Scale bar $=20 \mu \mathrm{m}$. (B) In the zebra finch, which is a highly gregarious species, isolation in a quiet room followed by exposure to a same-sex conspecific through a wire barrier produces a robust increase in VT neuronal activity in both males and females. Total $n=10$. (C) This same manipulation produces a significant decrease in VT-Fos colocalization in the territorial violet-eared waxbill, a species that does
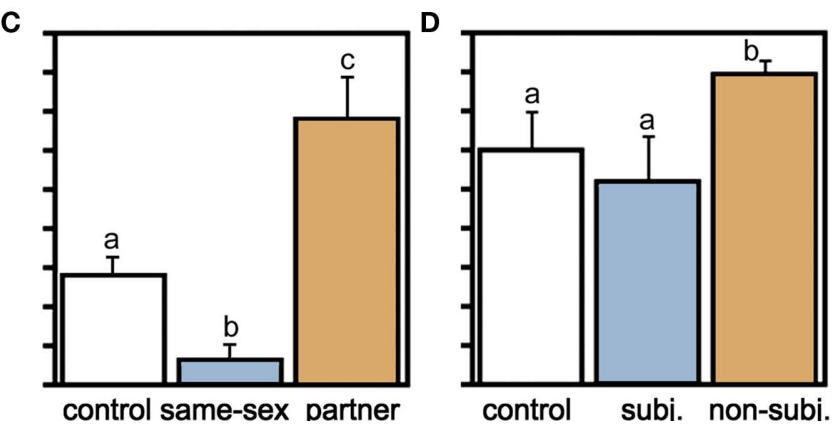

not naturally exhibit same-sex affiliation, but exposure to the subject's pairbond partner (a presumably positive stimulus), produces a robust increase in neuronal activity. Sexes are shown pooled. Total $n=16$. (D) VT-Fos colocalization increases in zebra finches following competition with a same-sex individual for courtship access to an opposite-sex bird, but not if the subject is paired with a highly aggressive partner and intensely subjugated. Subjugated animals were aggressively displaced or attacked 71-210 times during a 10-min interaction, demonstrating that social arousal alone does not increase VT-Fos colocalization in the BSTm. Sexes are shown pooled. Total $n=15$. (A) is modified from Goodson et al. (2009b); (B-D) are modified from Goodson and Wang (2006). to be interpreted as "sociality-related," we require that binding densities differ significantly between the two territorial and three flocking species (defined as contrast A) and differ significantly between the two territorial and two colonial species (contrast $\mathrm{B})$, with the modestly gregarious species being intermediate or falling in line with the two colonial species. The most convincing comparisons are those that meet these criteria, with additional significant differences between the territorial and gregarious Uraeginthus species, which are sympatric (contrast C). Sociality-related differences that meet this highest criterion are described as fitting an "ABC" pattern (Goodson et al., 2006). Figure 3 shows one such pattern for the density of $V_{1 a}$-like receptor density in the dorsal LS, and similar ABC species differences are observed in several other LS zones for both $\mathrm{V}_{1 \mathrm{a}}$-like, OT-like and VIP binding sites (Goodson et al., 2006, 2009c). Binding densities are mostly biased toward the gregarious species, although sociality-related differences in OT-like binding densities reverse along a dorso-ventral gradient, and the relative density between the pallial and subpallial LS provides the clearest differentiation of territorial and flocking species (Goodson et al., 2009c; Figure 4), suggesting that sociality is reflected in a complex neuromodulatory balance across the LS subnuclei. Outside of the LS, sociality-related differences in the finches are observed for VIP binding in the BSTm, which are biased toward the gregarious species (Goodson et al., 2006).

Densities of nonapeptide receptors in the LS are also highly variable in mammals, although the relevance of these species differences to behavior has largely been a matter of speculation (Insel et al., 1991, 1994; Campbell et al., 2009; Turner et al., 2010). However, recent findings suggest that OT receptor densities may reflect species differences in the provision of alloparental care by juvenile females, and alloparental care in female prairie voles is negatively correlated with OT receptor densities in the LS (Olazábal and Young, 2006). In male prairie voles, social investi- gation behavior is positively correlated with $\mathrm{V}_{\text {la }}$ receptor densities and negatively with OT receptor densities in the LS (Ophir et al., 2009).

\section{NONAPEPTIDES PROMOTE FLOCKING}

The relevance of nonapeptide receptors to grouping behavior has been directly confirmed by a series of recent experiments using central antagonist and antisense manipulations in zebra finches. Based on the well known effects of OT and OT receptors on affiliation in mammals (Carter et al., 2008; Goodson and Thompson, 2010), we began by blocking OT-like receptors (as in mammals, a single OT-like receptor has been identified in birds, VT3; Baeyens and Cornett, 2006). Using the choice apparatus shown in Figure 5A, in which subjects can choose between groups of 10 or 2 same-sex conspecifics (or not spend time near either), we first showed that subcutaneous and lateral ventricle infusions of an OT antagonist reduce preferences for the larger group (Figures 5B-E) without influencing the amount of time that subjects spent in close proximity to other birds (hereafter "contact time"). The peripheral effect was female-specific and ventricular infusions of MT produced a female-specific increase in the amount of time that subjects spent with large group, again with no effect on contact time. Infusions of the OT antagonist directly into the LS replicated the peripheral and ventricular antagonist effects in females, whereas control infusions into the medial striatum (adjacent to the ventricle) did not (Goodson et al., 2009c).

As described in the previous sections, gregarious species show a relatively greater social induction of Fos within VT neurons, more VT-ir neurons in the BSTm, and a higher density of VT $\mathrm{V}_{1 \mathrm{a}}$-like receptors in the LS than do territorial species (Goodson and Wang, 2006; Goodson et al., 2006), suggesting the hypothesis that VT projections from the BSTm to the LS promote sociality. Indeed, recent experiments in male zebra finches 

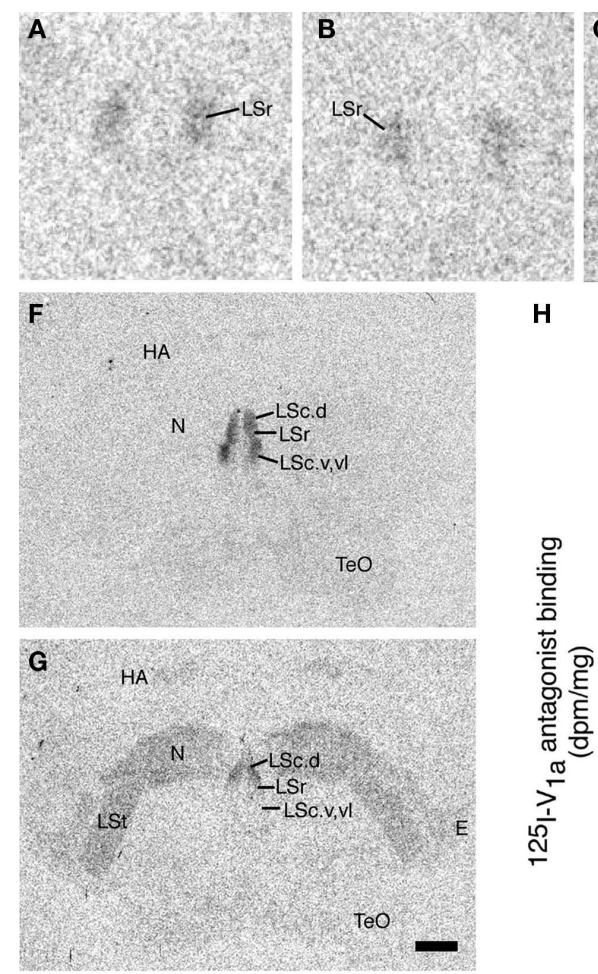

H
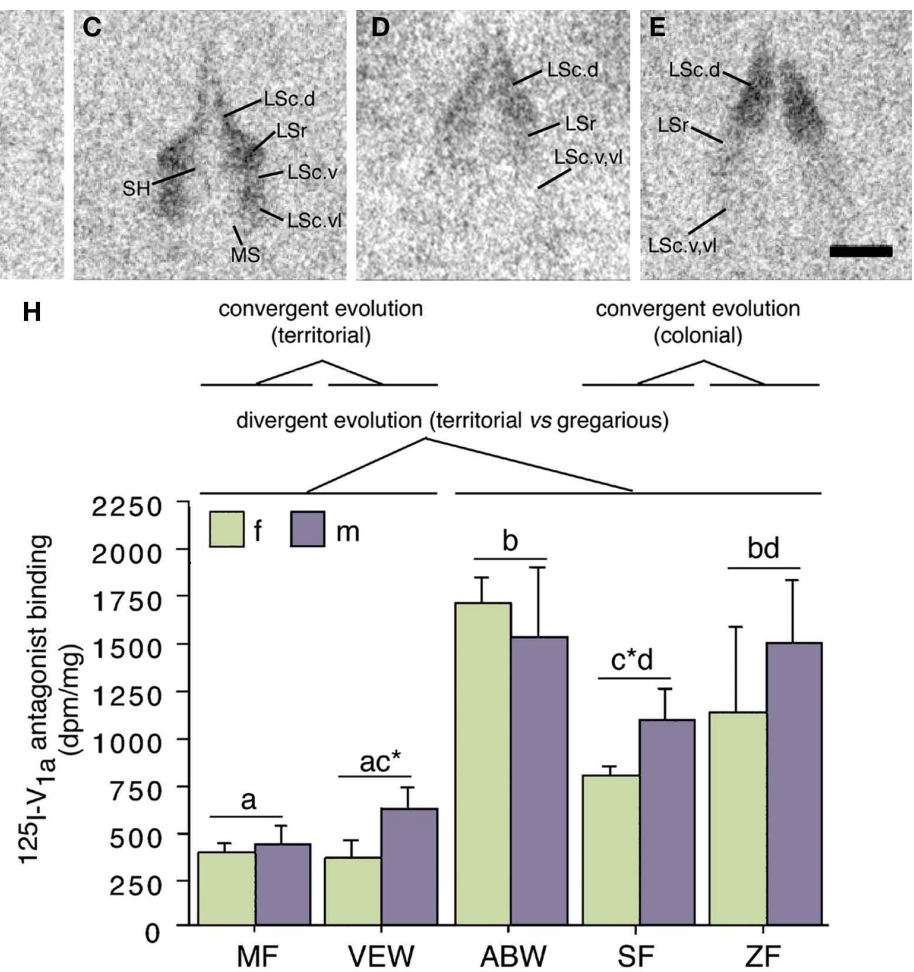

FIGURE 3 | Species differences in linear ${ }^{125} \mid-V_{1 a}$ antagonist binding in the lateral septum (LS) reflect evolutionary convergence and divergence in flocking and territoriality. (A-E) Representative ${ }^{125} \mid-\mathrm{V}_{1 \mathrm{a}}$ antagonist binding in the LS of the territorial Melba finch [MF; (A)], territorial violet-eared waxbill [VEW; (B)], moderately gregarious Angolan blue waxbill [ABW; (C)], colonial spice finch [SF; (D)], and colonial zebra finch [ZF; (E)]. The scale bar in (E) corresponds to $500 \mu \mathrm{m}$ in (A-E). (F,G) Representative sections for a male Angolan blue waxbill and male spice finch (colonial), respectively, showing species differences in binding for the nidopallium $(N)$ and other areas of the forebrain. The scale bar in (G) corresponds to $1 \mathrm{~mm}$ in $\mathbf{( F , G ) . ~ ( H ) ~ L i n e a r ~}{ }^{125} \mid-V_{1 a}$ antagonist binding in the dorsal (pallial) portion of the LS, shown as decompositions per $\mathrm{min} / \mathrm{mg}$ (dpm/mg; means \pm SEM). Different letters above the error bars denote significant species differences (Fisher's PLSD following significant ANOVA; $P<0.0001)$. Asterisks denote near-significant species differences $(P=0.06)$. Modified from Goodson et al. (2006). Abbreviations: $E$, entopallium; HA, apical part of the hyperpallium; LSc, caudal division of the lateral septum (dorsal, ventrolateral, and ventral zones denoted as LSc.d, LSc.vl, and LSc.v, respectively); LSr, rostral division of the lateral septum; LSt, lateral striatum; MS, medial septum; N, nidopallium; $\mathrm{SH}$, septohippocampal septum; TeO, optic tectum. demonstrate that knockdown of VT production in the BSTm by antisense oligonucleotides potently reduces gregariousness relative to subjects infused with scrambled oligonucleotides, with a median reduction of $80 \%$. "Gregariousness" in this experiment was defined as the percent of contact time that was spent next to a group of 10 conspecifics versus a group of 2 (Kelly et al., 2011). Surprisingly, this same manipulation increased contact time modestly relative to scrambled oligonucleotide controls (median difference of $25 \%$ ), although intraseptal infusions of a $\mathrm{V}_{\text {la }}$ antagonist produce no effects on contact time (and convincingly so). As with the VT antisense, intraseptal $\mathrm{V}_{\text {la }}$ antagonist infusions virtually eliminated subjects' preferences for the large group while concomitantly increasing the amount of time that subjects spent with the small group. The median reduction in gregariousness was again $80 \%$. We have further replicated this effect in both males and females using a novel $\mathrm{V}_{1 \mathrm{a}}$ antagonist that crosses the blood-brain barrier (JNJ-17308616; J. L. Goodson and S. E. Schrock, unpublished observations). In conjunction with both the antisense and central antagonist studies, we also conducted tests of anxiety-like behavior (novelty-suppressed feeding and exploration of a novel environment), which produced particularly intriguing results: whereas septal VP is usually found to be anxiogenic in rodents, it appears to be strongly anxiolytic in zebra finches (Kelly et al., 2011). Whether this difference is the result of unique receptor distributions and/or is an important factor in the social evolution of zebra finches remains to be determined. However, it is interesting in this light to note that septal VP may promote active stress coping in rats (Ebner et al., 1999), which are more social than laboratory mice and hamsters.

\section{CONCLUSION}

Using five finch species that are all socially monogamous and biparental, we have shown that (1) receptor distributions for multiple neuropeptide systems (VT/MT, VIP, and CRF) exhibit divergent and convergent evolution in relation to species-typical group size, particularly within the LS, (2) VT cells in the BSTm exhibit an exquisite sensitivity to the valence of social stimuli, thereby 

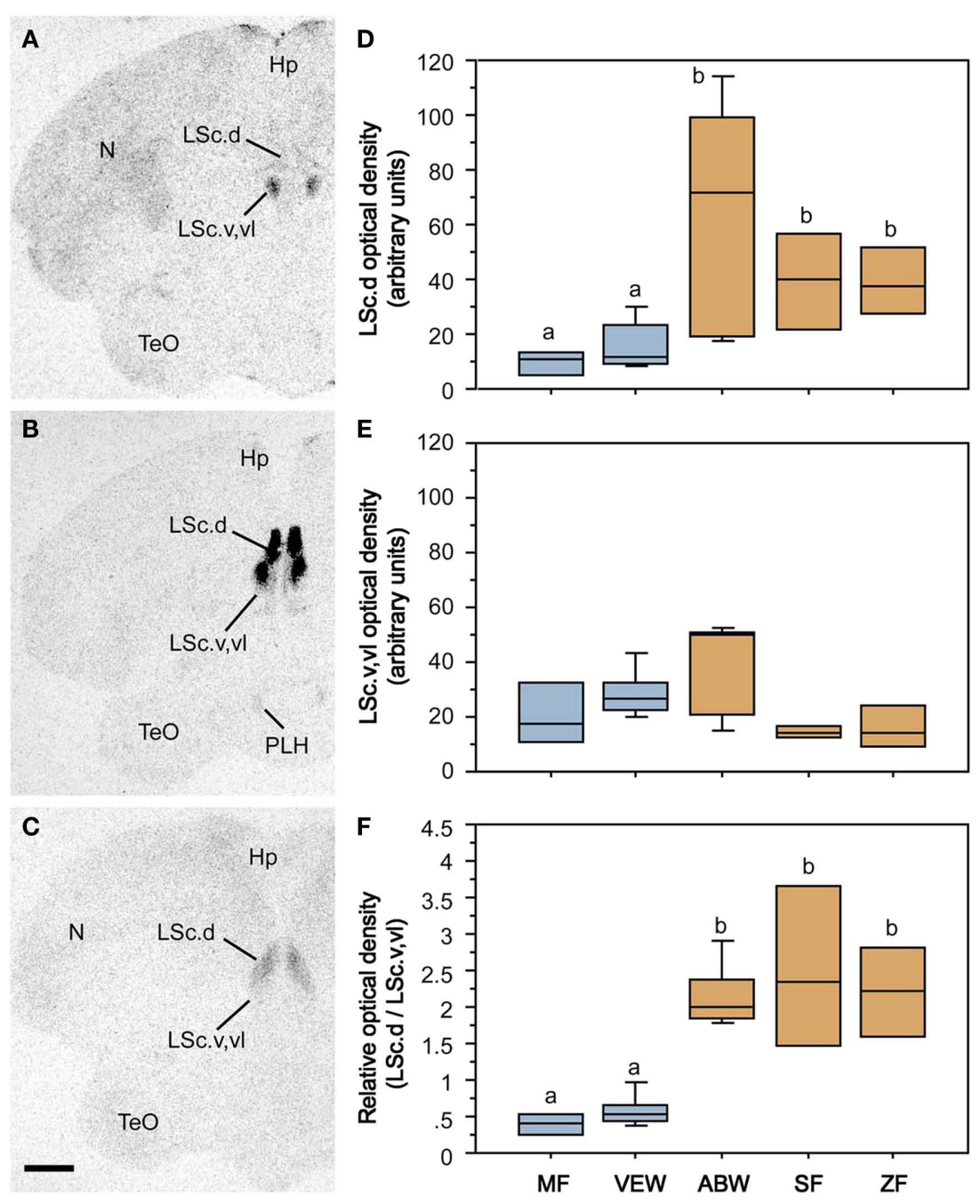

FIGURE 4 | Species-specific distributions of oxytocin-like binding sites reflect evolutionary convergence and divergence in flocking and territoriality. (A-C) Representative autoradiograms of ${ }^{125}$ |-OT antagonist binding sites in the caudal LS (LSC) in two sympatric, congeneric finches - the territorial violet-eared waxbill (A) and the gregarious Angolan blue waxbill (B), plus the highly gregarious zebra finch (C). (D) Densities of binding sites in the dorsal (pallial) LSc of two territorial species (Melba finch, MF, and violet-eared waxbill, VEW), a moderately gregarious species (Angolan blue waxbill, ABW), and two highly gregarious species (spice finch, SF, and zebra finch, ZF). No sex differences

creating differences between gregarious and territorial species in the response of their BSTm VT neurons to same-sex conspecifics, (3) endogenous nonapeptide signaling via $\mathrm{V}_{1 \mathrm{a}}$ - and OT-like receptors in the LS promotes preferences for larger groups in zebra finches without effects on social contact time, and (4) in male zebra finches, antisense knockdown of VT production in the BSTm profoundly reduces gregariousness. Although not discussed above, we have also found that the three flocking finch species exhibit relatively more dopamine neurons than do territorial species in a caudal subpopulation of cells in the ventral tegmental area that has also been implicated in appetitive courtship behavior (Goodson et al., 2009a). are observed and sexes were pooled. Total $n=23$. Different letters above the boxes denote significant species differences (Mann-Whitney $P<0.05$ ) following significant Kruskal-Wallis. (E) Binding densities tend to reverse in the subpallial LSc $(P=0.06)$, suggesting that species differences in sociality are most closely associated with the relative densities of binding sites along a dorso-ventral gradient, as confirmed in the bottom (F) using a dorsal:ventral ratio. Abbreviations: Hp, hippocampus; LSc.d, dorsal zone of the LSc; LSc.v,vl, ventral, and ventrolateral zones of the LSc; N, nidopallium; PLH, posterolateral hypothalamus; TeO, optic tectum. Modified from Goodson et al. (2009c).

A major remaining question is whether our results are predictive for other taxa. All of the neurochemical systems just mentioned influence myriad behavioral and physiological functions, thus we might expect that those systems may not evolve in relation to grouping, and in an estrildid-like manner, if other species-specific behavioral and physiological functions constrain the evolutionary process. This may occur if a given neural mechanism is under strong selection in relation to something other than grouping. At the same time, nonapeptides influence basic social behaviors across a wide range of vertebrates, suggesting that they may be common or even ubiquitous targets of selection during social evolution. 

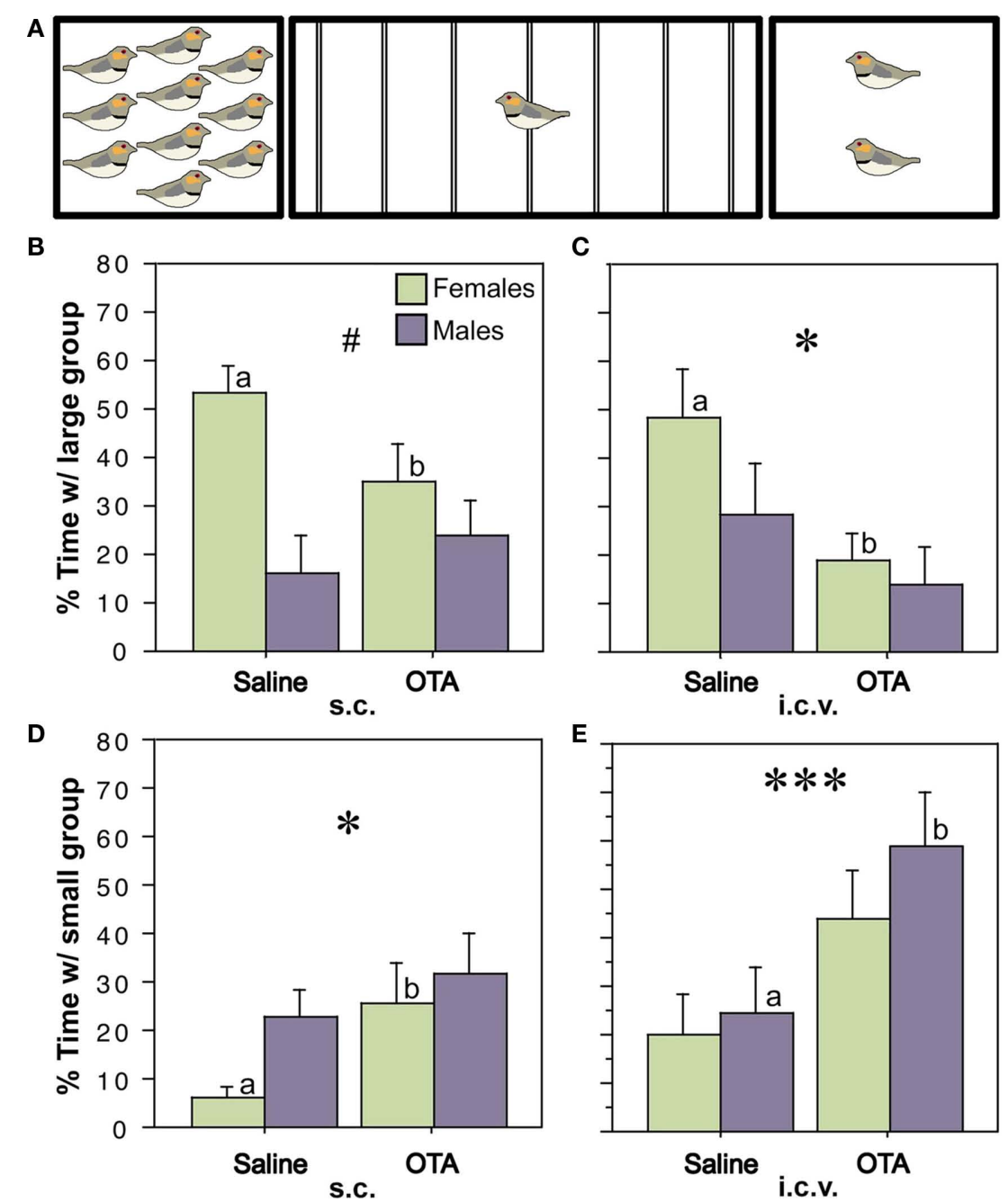

FIGURE 5 | Endogenous activation of oxytocin-like receptors promotes preferences for larger groups. (A) Choice apparatus design. A 1-m wide testing cage was subdivided into zones by seven perches (thin lines).

Subjects were considered to be within close proximity when they were within $6 \mathrm{~cm}$ of a stimulus cage (i.e., on the perches closest to the sides of the testing cage). The stimulus cages contained either 2 or 10 same-sex conspecifics. (B-E) Relative to vehicle treatments, subcutaneous (s.c.) or intracerebroventricular (i.c.v.) administrations of the oxytocin antagonist desGly- $\mathrm{NH}_{2}, \mathrm{~d}\left(\mathrm{CH}_{2}\right)_{5}\left[\mathrm{Tyr}(\mathrm{Me})^{2}\right.$, Thr $r^{4}$ OVT (OTA; $\left.250 \mathrm{ng}\right)$, reduce the amount of time that zebra finches spend in close proximity to the large group $(\mathbf{B}, \mathbf{C})$ and increase time in close proximity to the small group (D,E). ${ }^{*} P<0.05$, *** $P<0.001$, main effect of Treatment; $\# P<0.5$ Sex*Treatment; $n=12 \mathrm{~m}, 12$ $f$. Letters above the error bars denote significant within-sex effects. Modified from Goodson et al. (2009c).

\section{ACKNOWLEDGMENTS}

Our thanks to Aubrey M. Kelly, Richmond R. Thompson, Kristin Hoffbuhr, Sara E. Schrock, Brandon Waxman, David Kabelik, Yiwei Wang, James D. Klatt, Andrew K. Evans, and

\section{REFERENCES}

Acher, R. (1972). Chemistry of the Neurohypophysial Hormones: An Example of Molecular Evolution, Endocrinology, $119-130$. Washington, DC: American Physiological Society.

Alcock, J. (2009). Animal Behavior: An Evolutionary Approach, 9th Edn. Sunderland, MA: Sinauer Associates.
Alexander, R. D. (1974). The evolution of social behavior. Annu. Rev. Ecol. Syst. 5, 325-383.

Aragona, B. J., and Wang, Z. (2009). Dopamine regulation of social choice in a monogamous rodent species. Front. Behav. Neurosci. 3:15. doi: 10.3389/neuro.08.015.2009

Baeyens, D. A., and Cornett, L. E. (2006). The cloned avian neurohypophysial

Jacob Rinaldi for significant contributions to the work described here. Support for this work was provided by the National Institute of Mental Health grant MH062656 to James L. Goodson.

hormone receptors. Comp. Biochem. Physiol. B 143, 12-19.

Buntin, L., Berghman, L. R., and Buntin, J. D. (2006). Patterns of Fos-like immunoreactivity in the brains of parent ring doves (Streptopelia risoria) given tactile and nontactile exposure to their young. Behav. Neurosci. 120,651-664.

Campbell, P., Ophir, A. G., and Phelps, S. M. (2009). Central vasopressin and oxytocin receptor distributions in two species of singing mice. J. Comp. Neurol. 516, 321-333.

Carter, C. S., Grippo, A. J., PournajafiNazarloo, H., Ruscio, M. G., and Porges, S. W. (2008). Oxytocin, vasopressin and sociality. Prog. Brain Res. 170, 331-336.

Chaturvedi, C. M., and Prasad, S. K. (1991). Timed daily injections of 
neurotransmitter precursors alter the gonad and body weights of spotted munia, Lonchura punctulata, maintained under short daily photoperiods. J. Exp. Zool. 260, 194-201.

Choi, G. B., Dong, H. W., Murphy, A. J., Valenzuela, D. M., Yancopoulos, G. D., Swanson, L. W., and Anderson, D. J. (2005). Lhx6 delineates a pathway mediating innate reproductive behaviors from the amygdala to the hypothalamus. Neuron 46, 647-660.

Christidis, L. (1987a). Biochemical systematics within paleotropic finches (Aves: Estrildidae). Auk 104, 380-392.

Christidis, L. (1987b). Phylogeny and systematics of estrildine finches and their relationships to other seed-eating passerines. Emu 87, 119-123.

Clements, J.F. (2007). Birds of the World: A Checklist, 6th Edn. Sussex: Pica Press.

De Vries, G. J., and Buijs, R. M. (1983). The origin of the vasopressinergic and oxytocinergic innervation of the rat brain with special reference to the lateral septum. Brain Res. 273, 307-317.

De Vries, G. J., and Panzica, G. C. (2006). Sexual differentiation of central vasopressin and vasotocin systems in vertebrates: different mechanisms, similar endpoints. Neuroscience 138,947-955.

Delacour, J. (1943). A revision of the subfamily Estrildinae of the family Ploceidae. Zoologica 28, 69-86.

Donaldson, Z. R., and Young, L. J. (2008). Oxytocin, vasopressin, and the neurogenetics of sociality. Science 322,900-904.

Ebner, K., Wotjak, C. T., Holsboer, F., Landgraf, R., and Engelmann, M. (1999). Vasopressin released within the septal brain area during swim stress modulates the behavioural stress response in rats. Eur. J. Neurosci. 11, 997-1002.

Fink, S., Excoffier, L., and Heckel, G. (2006). Mammalian monogamy is not controlled by a single gene. Proc. Natl. Acad. Sci. U.S.A. 103, 10956-10960.

Goodenough, J., McGuire, B., and Jakob, E. (2010). Perspectives on Animal Behavior, 3rd Edn. Hoboken, NJ: John Wiley and Sons, Inc.

Goodson, J. L. (1998). Vasotocin and vasoactive intestinal polypeptide modulate aggression in a territorial songbird, the violet-eared waxbill (Estrildidae: Uraeginthus granatina). Gen. Comp. Endocrinol. 111, 233-244.

Goodson, J. L. (2005). The vertebrate social behavior network: evolutionary themes and variations. Horm. Behav. 48, 11-22.

Goodson, J. L. (2008). Nonapeptides and the evolutionary patterning of sociality. Prog. Brain Res. 170, 3-15.

Goodson, J. L., and Adkins-Regan, E. (1999). Effect of intraseptal vasotocin and vasoactive intestinal polypeptide infusions on courtship song and aggression in the male zebra finch (Taeniopygia guttata). J. Neuroendocrinol. 11, 19-25.

Goodson, J. L., and Bass, A. H. (2001). Social behavior functions and related anatomical characteristics of vasotocin/vasopressin systems in vertebrates. Brain Res. Rev. 35, 246-265.

Goodson, J. L., Eibach, R., Sakata, J., and Adkins-Regan, E. (1999). Effect of septal lesions on male song and aggression in the colonial zebra finch (Taeniopygia guttata) and the territorial field sparrow (Spizella pusilla). Behav. Brain Res. 98, 167-180.

Goodson, J. L., and Evans, A. K. (2004) Neural responses to territorial challenge and nonsocial stress in male song sparrows: segregation, integration, and modulation by a vasopressin V1 antagonist. Horm. Behav. 46, 371-381.

Goodson, J. L., Evans, A. K., Lindberg, L., and Allen, C. D. (2005a). Neuroevolutionary patterning of sociality. Proc. R. Soc. Lond., B, Biol. Sci. 272, 227-235.

Goodson, J. L., Evans, A. K., and Soma, K. K. (2005b). Neural responses to aggressive challenge correlate with behavior in nonbreeding sparrows. Neuroreport 16, 1719-1723.

Goodson, J. L., Evans, A. K., and Wang, Y. (2006). Neuropeptide binding reflects convergent and divergent evolution in species-typical group sizes. Horm. Behav. 50, 223-236.

Goodson, J. L., and Kabelik, D. (2009). Dynamic limbic networks and social diversity in vertebrates: from neural context to neuromodulatory patterning. Front. Neuroendocrinol. 30:4. doi: 10.1016/j.yfrne.2009.05.007

Goodson, J. L., Kabelik, D., Kelly, A. M. Rinaldi, J., and Klatt, J. D. (2009a) Midbrain dopamine neurons reflect affiliation phenotypes in finches and are tightly coupled to courtship. Proc. Natl. Acad. Sci. U.S.A. 106, 8737-8742.

Goodson, J. L., Rinaldi, J., and Kelly, A. M. (2009b).Vasotocin neurons in the bed nucleus of the stria terminalis preferentially process social information and exhibit properties that dichotomize courting and non-courting phenotypes. Horm. Behav. 55, 197-202.

Goodson, J. L., Schrock, S. E., Klatt, J. D., Kabelik, D., and Kingsbury, M. A. (2009c). Mesotocin and nonapeptide receptors promote estrildid flocking behavior. Science 325, 862-866.

Goodson, J. L., Lindberg, L., and Johnson, P. (2004). Effects of central vasotocin and mesotocin manipulations on social behavior in male and female zebra finches. Horm. Behav. 45, 136-143.

Goodson, J. L., and Thompson, R. R. (2010). Nonapeptide mechanisms of social cognition, behavior and species-specific social systems. Curr. Opin. Neurobiol. 20, 784-794.

Goodson, J. L., and Wang, Y. (2006) Valence-sensitive neurons exhibit divergent functional profiles in gregarious and asocial species. Proc. Natl. Acad. Sci. U.S.A. 103, 17013-17017.

Goodwin, D. (1982). Estrildid Finches of the World. Ithaca, NY: Cornell University Press.

Hahn, T. P., and MacDougall-Shackleton, S. A. (2008). Adaptive specialization, conditional plasticity and phylogenetic history in the reproductive cue response systems of birds. Philos. Trans. R. Soc. Lond., B, Biol. Sci. 363 267-286.

Harrison, C. J. O. (1962). An ethological comparison of some waxbills (Estrildini) and its relevance to their taxonomy. Proc. Zool. Soc. Lond. 139, 261-282.

Herdegen, T., and Leah, J. D. (1998) Inducible and constitutive transcription factors in the mammalian nervous system: control of gene expression by Jun, Fos and Krox, and CREB/ATF proteins. Brain Res. Rev. 28, 370-490.

Ho, J. M., Murray, J. H., Demas, G. E., and Goodson, J. L. (2010). Vasopressin cell groups exhibit strongly divergent responses to copulation and malemale interactions in mice. Horm Behav. 58, 368-377.

Hoyle, C. H. V. (1999). Neuropeptide families and their receptors: evolutionary perspectives. Brain Res. 848, 1-25. Immelmann, K. (1965). Australian Finche in Bush and Aviary. Sydney: Angus and Robertson.

Insel, T. R. (2010). The challenge of translation in social neuroscience: a review of oxytocin, vasopressin, and affiliative behavior. Neuron 65, 768-779.

Insel, T. R., Gelhard, R., and Shapiro, L. E. (1991). The comparative distribution of forebrain receptors for neurohypophyseal peptides in monogamous and polygamous mice. Neuroscience 43, 623-630.

Insel, T. R., Wang, Z. X., and Ferris, C. F (1994). Patterns of brain vasopressin receptor distribution associated with social organization in microtine rodents. J. Neurosci. 14, 5381-5392.

Kabelik, D., Klatt, J. D., Kingsbury, M. A., and Goodson, J. L. (2009) Endogenous vasotocin exerts context-dependent behavioral effects in a semi-naturalistic colony environment. Horm. Behav. 56, 101-107.

Kabelik, D., Morrison, J.A., and Goodson, J.L. (2010). Cryptic regulation of vasotocin neuronal activity but not anatomy by sex steroids and social stimuli in opportunistic desert finches. Brain Behav. Evol. 75, 71-84.

Kelly, A. M., Kingsbury, M. A., Hoffbuhr, K., Schrock, S.E., Waxman, B., Kabelik,
D., Thompson, R. R., and Goodson, J. L. (2011). Vasotocin neurons and septal V1a-like receptors potently modulate finch flocking and responses to novelty. Horm. Behav. doi: 10.1016/j. yhbeh.2011.01.012. [Epub ahead of print].

King, J. A. (ed.). (1968). Biology of Peromyscus (Rodentia). Stillwater, MN: American Society of Mammalogists.

Kingsbury, M. A., Kelly, A. K., Schrock, S. E., and Goodson, J. L. (2011). Mammal-like organization of the avian midbrain central gray and a reappraisal of the intercollicular nucleus. PLoS ONE (in press).

Kollack-Walker, S., Watson, S. J., and Akil, H. (1997). Social stress in hamsters: defeat activates specific neurocircuits within the brain. J. Neurosci. 17, 8842-8855.

Krause, J., and Ruxton, G. D. (2002). Living in Groups. Oxford: Oxford University Press.

Lei, K., Cushing, B. S., Musatov, S., Ogawa, S., and Kramer, K. M. (2010). Estrogen receptor-alpha in the bed nucleus of the stria terminalis regulates social affiliation in male prairie voles (Microtus ochrogaster). PLoS ONE 5, e8931. doi: 10.1371/journal. pone.0008931

Ludwig, M., and Leng, G. (2006). Dendritic peptide release and peptide-dependent behaviours. Nat. Rev. Neurosci. 7, 126-136.

Maney, D. L., and Ball, G. F. (2003). Foslike immunoreactivity in catecholaminergic brain nuclei after territorial behavior in free-living song sparrows. J. Neurobiol. 56, 163-170.

Maney, D. L., Goode, C. T., Lange, H. S. Sanford, S. E., and Solomon, B. L. (2008). Estradiol modulates neural responses to song in a seasonal songbird. J. Comp. Neurol. 511, 173-186.

Martinez-Garcia, F., Novejarque, A., and Lanuza, E. (2008). Two interconnected functional systems in the amygdala of amniote vertebrates. Brain Res. Bull. 75, 206-213.

Mayr, E. (1968). The sequence of genera in the Estrildidae (Aves). Breviora 287 $1-14$.

McGraw, L. A., and Young, L. J. (2010). The prairie vole: an emerging mode organism for understanding the social brain. Trends Neurosci. 33, 103-109.

Moller, A. P., and Birkhead, T. R. (1993). Cuckoldry and sociality: a comparative study in birds. Am. Nat. 142, 118-140.

Moore, F. L., and Lowry, C. A. (1998). Comparative neuroanatomy of vasotocin and vasopressin in amphibians and other vertebrates. Comp. Biochem. Physiol. C Pharmacol. Toxicol. Endocrinol. 119, 251-260.

Morris, D. (1958). The comparative ethology of grassfinches (Erythrurae) and 
mannikins (Amadinae). Proc.Zool. Sci. Lond. 131, 389-439.

Motta, S. C., Goto, M., Gouveia, F. V., Baldo, M. V. C., Canteras, N. S., and Swanson, L. W. (2009). Dissecting the brain's fear system reveals the hypothalamus is critical for responding in subordinate conspecific intruders. Proc. Natl. Acad. Sci. U.S.A. 106, 4870-4875.

Neumann, I. D. (2009). The advantage of social living: brain neuropeptides mediate the beneficial consequences of sex and motherhood. Front. Neuroendocrinol. 30:4. doi: 10.1016/j. yfrne.2009.04.012

Newman, S. W. (1999). The medial extended amygdala in male reproductive behavior: a node in the mammalian social behavior network. Ann. N. Y. Acad. Sci. 877, 242-257.

Nishijo, H., Ono, T., and Nishino, H. (1988). Single neuron responses in amygdala of alert monkey during complex sensory stimulation with affective significance. J. Neurosci. 8 , 3570-3583.

Northcutt, R. G. (2008). Forebrain evolution in bony fishes. Brain Res. Bull. 75, 191-205.

Olazábal, D. E., and Young, L. J. (2006). Species and individual differences in juvenile female alloparental care are associated with oxytocin receptor density in the striatum and the lateral septum. Horm. Behav. 49, 681-687.

Ophir, A. G., Zheng, D.-J., Eans, S., and Phelps, S. M. (2009). Social investigation in a memory task relates to natural variation in septal expression of oxytocin receptor and vasopressin receptor 1a in prairie voles (Microtus ochrogaster). Behav. Neurosci. 123, 979-991.

Paton, J. J., Belova, M. A., Morrison, S. E., and Salzman, C. D. (2006). The primate amygdala represents the positive and negative value of visual stimuli during learning. Nature 439, 865-870.

Payne, R. B. (1998). A new species of firefinch Lagonosticta from northern Nigeria and its association with the Jos Plateau indigobird Vidua maryae. Ibis 140, 368-381.

Pollen, A. A., and Hofmann, H. A. (2008). Beyond neuroanatomy: novel approaches to studying brain evolution. Brain Behav. Evol. 72, 145-158.

Ross, H. E., and Young, L. J. (2009). Oxytocin and the neural mechanisms regulating social cognition and affiliative behavior. Front. Neuroendocrinol.30:4. doi: 10.1016/j. yfrne.2009.05.004

Sheehan, T. P., Paul, M., Amaral, E., Numan, M. J., and Numan, M. (2001). Evidence that the medial amygdala projects to the anterior/ventromedial hypothalamic nuclei to inhibit maternal behavior in rats. Neuroscience 106, 341-356.

Sikdar, M., Kar, A., and Prakash, P. (1992). Role of humidity in the seasonal reproduction of male spotted munia, Lonchura punctulata. J. Exp. Zool.264, 82-84.
Silk, J. B. (2007). The adaptive value of sociality in mammalian groups. Philos. Trans. R. Soc. Lond., B, Biol. Sci. 362, 539-559.

Skead, D. M. (1975). Ecological studies of four estrildines in the central Transvaal. Ostrich 11 (Suppl.), 1-55.

Sorenson, M. D., Balakrishnan, C. N., and Payne, R. B. (2004). Clade-limited colonization in brood parasitic finches (Vidua spp.). Syst. Biol. 53, 140-153.

Tamarin, R. H. (ed.). (1985). Biology of New World Microtus. Stillwater, OK: American Society of Mammalogists.

Tessmar-Raible, K., Raible, F. Christodoulou, F., Guy, K., Rembold, M., Hausen, H., and Arendt, D. (2007) Conserved sensory-neurosecretory cell types in annelid and fish forebrain: insights into hypothalamus evolution. Cell 129, 1389-1400.

Trainor, B. C., Greiwe, K. M., and Nelson, R. J. (2006). Individual differences in estrogen receptor $\alpha$ in select brain nuclei are associated with individual differences in aggression. Horm. Behav. 50, 338-345.

Trainor, B. C., Lin, S., Finy, M. S. Rowland, M. R., and Nelson, R. J. (2007). Photoperiod reverses the effects of estrogens on male aggression via genomic and nongenomic pathways. Proc. Natl. Acad. Sci. U.S.A. 104, 9840-9845.

Turner, L. M., Young, A. R., Rompler, H., Schoneberg, T., Phelps, S. M., and Hoekstra, H. E. (2010). Monogamy evolves through multiple mechanisms: evidence from V1aR in deer mice. $\mathrm{Mol}$. Biol. Evol. 27, 1269-1278.

Veenema, A. H., and Neumann, I. D. (2008). Central vasopressin and oxytocin release: regulation of complex social behaviours. Prog. Brain Res. 170, 261-276.

Zann, R. A. (1996). The Zebra Finch: A Synthesis of Field and Laboratory Studies. Oxford: Oxford University Press.

Ziegler, A. P. (1971). Habitat and breeding of the grey-headed olive-back Nesocharis capistrata in northern Uganda. Ibis 113, 238-240.

Conflict of Interest Statement: The authors declare that the research was conducted in the absence of any commercial or financial relationships that could be construed as a potential conflict of interest.

Received: 31 October 2010; paper pending published: 21 December 2010; accepted: 16 February 2011; published online: 02 March 2011.

Citation: Goodson JL and Kingsbury MA (2011) Nonapeptides and the evolution of social group sizes in birds. Front. Neuroanat. 5:13. doi: 10.3389/fnana.2011.00013 Copyright $\odot 2011$ Goodson and Kingsbury. This is an open-access article subject to an exclusive license agreement between the authors and Frontiers Media SA, which permits unrestricted use, distribution, and reproduction in any medium, provided the original authors and source are credited. 